\title{
Konsumsi Makanan Ibu Hamil Berhubungan dengan Berat Badan Lahir Bayi di Daerah Pesisir
}

\author{
${ }^{1}$ Juminten Saimin, ${ }^{2}$ Ade Rizky Amalia, ${ }^{2}$ Ashaeryanto, ${ }^{3}$ Asmarani \\ ${ }^{1}$ Bagian Obstetri dan Ginekologi Fakultas Kedokteran Universitas Halu Oleo \\ ${ }^{2}$ Bagian Biomedik Fakultas Kedokteran Universitas Halu Oleo \\ ${ }^{3}$ Bagian Ilmu Kesehatan Masyarakat Fakultas Kedokteran Universitas Halu Oleo \\ Email: inten_azis@yahoo.com
}

\begin{abstract}
Background: Low nutritional intake during pregnancy and nutritional status of pregnant women cause various effects for mother and babies. One of the effects is low birth weight. The prevalence of LBW in coastal areas is still high. This study aims to determine the relationship between eating habits of pregnant women with birth weight in coastal areas.Method: This study was an observational analytic study using a cross-sectional method. The sample were 50 respondents obtained using the consecutive sampling method. Data collection on eating habits used a food frequency questionnaire (FFQ). Data analysis used Fisher's Exact test with a significance value of $p<0.05$.

Results: The results showed that infant birth weight in coastal areas was associated with the habits of pregnant women eating carbohydrate sources $(p=0.45)$, protein sources $(p=0.17)$ and vegetables $(p=0.006)$. Infant birth weight in coastal areas was not related to the habits of pregnant women eating fruit $(p=1.00)$. Conclusion: There was a relationship between infant birth weight in coastal areas and the habit of pregnant women eating carbohydrates sources, protein sources and vegetables. There was no relationship between infant birth weight in coastal areas and the habit of pregnant women eating fruits.
\end{abstract}

Keywords :Birth weight, eating habits, pregnant women

\section{PENDAHULUAN}

Ibu hamil merupakan salah satu kelompok rawan kekurangan gizi. Selama kehamilan terjadi peningkatan kebutuhan gizi untuk memenuhi kebutuhan ibu dan janinnya (Ojofeitimi dkk., 2008). Masalah gizi yang terjadi pada ibu hamil akan berdampak negatif bagi ibu dan perkembangan janin. Masalah gizi merupakan masalah kesehatan masyarakat terutama di negara berkembang termasuk Indonesia. Masalah gizi menjadi penyebab kematian ibu dan anak yang sebenarnya masih dapat dicegah. Asupan gizi yang rendah dan status gizi ibu hamil dapat menimbulkan berbagai dampak bagi ibu dan janin. Salah satunya adalah bayi lahir dengan berat lahir rendah (Kemenkes RI, 2014).

Kesehatan ibu selama masa kehamilan sangat bepengaruh terhadap tumbuh kembang janin. Oleh karena itu, diharapkan ibu hamil dapat mengontrol pola makannya. Pemenuhan gizi ibu hamil dapat diukur dengan peningkatan berat badan dan ukuran lingkar lengan atas (Saimin dan Manoe, 2006; Saimin dkk., 2017). Pertambahan berat badan untuk ibu hamil dengan berat badan normal selama trimester pertama 1-2 kg, trimester kedua dan ketiga 0,34-0,5 kg/minggu (Proverawati, 2009).

Hasil Riskesdas tahun 2013 menyatakan bahwa persentase balita dengan berat badan lahir rendah (BBLR) sebesar 10,2\% (Kemenkes RI, 2014). Menurut data 
Dinas Kesehatan Propinsi Sulawesi Tenggara (2016) persentase BBLR tertinggi terdapat di Puskesmas Nambo (6,88\%), Puskesmas Puwatu (5,35\%) dan Puskesmas Mata (3,32\%).

Bayi lahir dengan BBLR berisiko mengalami kematian di usia neonatal. Menurut laporan World Bank (2006) bayi lahir dengan BBLR lebih rentan terhadap kejadian kegemukan dan berisiko menderita Non Communicable Diseases (NCD) di usia dewasa. Konsekuensi meningkatnya prevalensi penderita penyakit degeneratif di usia dewasa selain memerlukan biaya perawatan kesehatan yang tinggi juga akan menurunkan produktivitas. Oleh karena itu, untuk meningkatkan kualitas manusia harus dimulai sedini mungkin sejak janin dalam kandungan (World Bank, 2006).

Berat badan lahir berhubungan dengan pemenuhan nutrisi selama kehamilan, yaitu kebutuhan zat gizi makro. Kebutuhan gizi meningkat seiring bertambahnya usia kehamilan, pertumbuhan dan perkembangan janin bersama dengan perubahan jaringan serta metabolisme tubuh ibu. Pertumbuhan dan perkembangan janin semakin cepat pada kehamilan trimester ketiga sehingga diperlukan asupan energi dan protein yang cukup.Tingkat kecukupan gizi selama hamil berpengaruh terhadap berat badan lahir (Arkkola, 2009).

Berdasarkan penjelasan di atas diketahui bahwa persentase BBLR masih tinggi di daerah pesisir Kota Kendari dan berat badan lahir bayi dipengaruhi oleh asupan nutrisi dari ibu selama hamil, namun belum ada penelitian yang di lakukan pada masyarakat pesisir terutama di wilayah Kota Kendari, Sulawesi Tenggara. Daerah pesisir adalah daerah pertemuan antara darat dan laut yang kaya sumber daya alam terutama sumber daya alam dari laut yang dapat digunakan sebagai sumber bahan makanan untuk memenuhi kebutuhan gizi ibu selama hamil. Oleh karena itu, penelitian ini perlu dilakukan untuk mengetahui apakah terdapat hubungan antara kebiasaan makan ibu hamil dan berat badan lahir bayi di daerah pesisir.

\section{METODE PENELITIAN}

Penelitian ini merupakan penelitian analitik observasional dengan rancangan cross sectional. Penelitian ini dilaksanakan pada bulan Desember 2016 di wilayah kerja Puskesmas Mata, Puskesmas Abeli dan Puskesmas Nambo.

Populasi penelitian ini adalah semua wanita berusia 20-35 tahun yang melahirkan di wilayah kerja Puskesmas Mata, Puskesmas Abeli dan Puskesmas Nambodi Kota Kendari Sulawesi Tenggara. Pengambilan sampel secara consecutive sampling, dengan jumlah sampel sebanyak 50 responden. Analisis data menggunakan uji Fisher's Exact dengan nilai signifikansi $\mathrm{p}<0,05$.

\section{HASIL}

Berdasarkan Tabel 1 diketahui bahwa responden terbanyak adalah berusia 20-25 tahun $(38,0 \%)$, berpendidikan terakhir SMA $(42,0 \%)$, multipara $(82,0 \%)$ dan pekerjaan suami di swasta $(28,0 \%)$. 
Tabel 1. Karakteristik Responden

\begin{tabular}{lcc}
\hline \multicolumn{1}{c}{ Karakteristik } & n & \% \\
\hline Usia & & \\
20-25 & 19 & 38.0 \\
$26-30$ & 14 & 28.0 \\
$31-35$ & 17 & 34.0 \\
Pendidikan & & \\
$\quad$ SD & 12 & 24.0 \\
SMP & 12 & 24.0 \\
SMA & 21 & 42.0 \\
PT & 5 & 10.0 \\
Paritas & & \\
$\quad$ Primipara & 7 & 14.0 \\
$\quad$ Multipara & 41 & 82.0 \\
Grandemultipara & 2 & 4.0 \\
Pekerjaan Suami & & \\
Swasta & 28 & 56.0 \\
Nelayan & 18 & 36.0 \\
PNS & 4 & 8.0 \\
\hline
\end{tabular}

Tabel 2. Frekuensi Pangan Ibu Hamil

\begin{tabular}{lcc}
\hline \multicolumn{1}{c}{ Frekuensi Pangan } & n & \% \\
\hline Konsumsi Karbohidrat & & \\
$\quad$ Sering & 26 & 52.0 \\
$\quad$ Jarang & 24 & 48.0 \\
Konsumsi Protein & & \\
$\quad$ Sering & 21 & 42.0 \\
$\quad$ Jarang & 29 & 58.0 \\
Konsumsi Sayur & & \\
$\quad$ Sering & 32 & 64.0 \\
$\quad$ Jarang & 18 & 36.0 \\
Konsumsi Buah & & \\
$\quad$ Sering & 26 & 52.0 \\
$\quad$ Jarang & 24 & 48.0 \\
\hline
\end{tabular}

Pada Tabel 2 dapat dilihat bahwa responden terbanyak adalah sering mengkonsumsi bahan makanan sumber karbohidrat $(52,0 \%)$, jarang mengkonsumsi sumber protein $(58,0 \%)$, sering mengkonsumsi sayur $(64,0 \%)$, dan sering mengkonsumsi buah $(52,0 \%)$. Tabel 3 menunjukkan bahwa terdapat $86,0 \%$ BBLN dan $14,0 \%$ BBLR.

Tabel 3. Frekuensi Berat Badan Lahir

\begin{tabular}{ccc}
\hline Berat Badan Lahir & n & \% \\
\hline Berat Badan Lahir Normal & 43 & 86.0 \\
Berat Badan Lahir Rendah & 7 & 14.0 \\
\hline
\end{tabular}

Tabel 4 menunjukkan bahwa responden yang sering mengkonsumsi sumber karbohidrat 50,0\% melahirkan bayi BBLN dan 2,0\% melahirkan bayi BBLR. Responden yang jarang mengkonsumsi karbohidrat 36,0\% melahirkan bayi BBLN dan 12,0\% melahirkan bayi BBLR. Hasil uji Fisher exact diperoleh nilai $\mathrm{p}=0,045$ yang menunjukkan bahwa terdapat hubungan antara kebiasaan ibu hamil mengkonsumsi karbohidrat dengan berat badan lahir bayi.

Pada Tabel 4 tampak bahwa seluruh responden yang sering mengkonsumsi sumber protein melahirkan bayi BBLN (42,0\%). Responden yang jarang mengkonsumsi sumber protein $44,0 \%$ melahirkan bayi BBLN dan 14,0\% melahirkan bayi BBLR. Hasil uji Fisher exact diperoleh nilai $\mathrm{p}=0,017$ yang berarti bahwa terdapat hubungan antara kebiasaan ibu hamil mengkonsumsi sumber protein dengan berat badan lahir bayi. 
Tabel 4. Hubungan Frekuensi Sumber Karbohidrat, Protein, \& Buah dengan Berat Badan Lahir

\begin{tabular}{|c|c|c|c|c|c|c|c|c|}
\hline \multirow{3}{*}{\multicolumn{2}{|c|}{$\begin{array}{c}\text { Frekuensi sumber } \\
\text { pangan }\end{array}$}} & \multicolumn{4}{|c|}{$\mathrm{BBL}$} & \multirow{2}{*}{\multicolumn{2}{|c|}{ Total }} & \multirow{3}{*}{ p-value* } \\
\hline & & \multicolumn{2}{|c|}{ BBLN } & \multicolumn{2}{|c|}{ BBLR } & & & \\
\hline & & $\mathrm{n}$ & $\%$ & $\mathrm{n}$ & $\%$ & $\mathrm{~N}$ & $\%$ & \\
\hline \multirow{2}{*}{ Karbohidrat } & Sering & 25 & 50,0 & 1 & 2,0 & 26 & 52,0 & \multirow{2}{*}{0,045} \\
\hline & Jarang & 18 & 36,0 & 6 & 12,0 & 24 & 48,0 & \\
\hline \multirow{2}{*}{ Protein } & Sering & 21 & 42,0 & 0 & 0,0 & 21 & 42,0 & \multirow{2}{*}{0,017} \\
\hline & Jarang & 22 & 44,0 & 7 & 14,0 & 29 & 58,0 & \\
\hline \multirow{2}{*}{ Sayur } & Sering & 31 & 62,0 & 1 & 2,0 & 32 & 64,0 & \multirow{2}{*}{0,006} \\
\hline & Jarang & 12 & 24,0 & 6 & 12,0 & 18 & 36,0 & \\
\hline \multirow{2}{*}{ Buah } & Sering & 25 & 56,0 & 1 & 2,0 & 26 & 58,0 & \multirow{2}{*}{1,000} \\
\hline & Jarang & 18 & 30,0 & 6 & 12,0 & 24 & 42,0 & \\
\hline
\end{tabular}

Keterangan: uji Fisher's Exact dengan nilai signifik $\mathrm{p}<0,05$

Tabel 4 juga menunjukkan bahwa responden yang sering mengkonsumsi sayur $62,0 \%$ melahirkan bayi BBLN dan 2,0\% melahirkan bayi BBLR. Responden yang jarang 24,0\% melahirkan bayi BBLN dan $12,0 \%$ melahirkan bayi BBLR. Hasil uji Fisher exact diperoleh nilai $\mathrm{p}=0,006$ yang berarti bahwa terdapat hubungan antara frekuensi konsumsi sayur dengan berat badan lahir bayi. Selain itu, responden yang sering konsumsi buah 56,0\% melahirkan bayi BBLN dan 2\% melahirkan bayi BBLR. Responden yang jarang konsumsi buah $30,0 \%$ melahirkan bayi BBLN dan 12,0\% melahirkan bayi BBLR. Hasil uji Fisher exact diperoleh nilai $\mathrm{p}=1,000$ yang menunjukkan bahwa tidak terdapat hubungan antara kebiasaan makan buah dengan berat badan lahir bayi.

\section{PEMBAHASAN}

Pada penelitian di daerah pesisir ini responden terbanyak berusia 20-25 tahun.Usia ibu saat hamil merupakan salah satu faktor yang mempengaruhi kesehatan ibu dan janin. Usia reproduksi sehat adalah 20-35 tahun. Kehamilan yang terjadi pada usia $<20$ dan $>35$ tahun merupakan kehamilan risiko tinggi yang dapat mempengaruhi kesehatan ibu dan janin, termasuk BBLR. Kehamilan pada usiayang sangat muda dapat mengakibatkan terjadi persaingan nutrisi antara perkembangan fisik ibu hamil usia muda dengan janin yang dikandungnya. Pada masa remaja sangat dibutuhkan kalori danenergi untuk proses pertumbuhan, sehingga dapat berdampak kurangnya asupan nutrisi pada janin yang dikandung (Ullah, 2003; Kumar, 2017). 
Hasil penelitian ini menunjukkan bahwa responden terbanyak berpendidikan terakhir SMA. Tingkat pendidikan mempunyai peranan yang penting terhadap sikap dan perilaku kesehatan seseorang. Ibu hamil dengan tingkat pendidikan yang lebih baik akan cenderung mencari informasi terkait kehamilannya (Sediaoetama, 2008).

Hasil penelitian menunjukkan bahwa terdapat hubungan antara kebiasaan ibu hamil mengkonsumsi sumber karbohidrat dengan berat badan lahir bayi didaerah pesisir. Responden yang memiliki asupan karbohidrat yang sering lebih sedikit melahirkan bayi BBLR dibandingkan yang jarang. Namun masih juga didapatkan yang melahirkan BBLR. Hal ini dapat disebabkan karena asupan karbohidrat tidak diimbangi dengan nutrisi makro dan mikro lainnya.

Penelitian pada hewan coba juga menunjukkan bahwa hewan yang dibatasi konsumsi kalori selama kehamilan umumnya melahirkan dengan berat lahir rendah (Boer dkk., 2009).

Hasil penelitian ini menunjukkan adanya hubungan yang bermakna antara asupan protein ibu hamil dengan berat badan lahir bayi di daerah pesisir. Responden yang memiliki asupan protein yang sering tidak ada yang melahirkan BBLR sedangkan yang frekuensinya jarang semuanya melahirkan bayi BBLR. Hal ini sejalan dengan yang dikemukakan oleh Boer dkk. (2009) bahwa pada manusia dan hewan coba menunjukkan bahwa asupan protein yang rendah selama kehamilan dapat menyebabkan penurunan berat badan lahir bayi dibandingkan dengan asupan protein yang normal.
Hasil penelitian ini menunjukkan adanya hubungan antara frekuensi pangan sayur pada ibu hamil dengan berat badan lahir bayi di daerah pesisir. Dari data didapatkan bahwa terdapat responden yang mengkonsumsi sayur dengan frekuensi jarang disertai pula dengan jarangnya mengkonsumsi karbohidrat dan protein sehingga total energi yang dikonsumsi pada saat hamil kurang dan melahirkan bayi BBLR. Penelitian yang sejalan juga mendapatkan bahwa bayi BBLR berhubungan dengan kurangnya konsumsi karbohidrat pada ibu hamil. Rata-rata ibu hamil kurang mengkonsumsi makanan yang mengandung gizi mikro (Shaikh dkk., 2014).

Beberapa penelitian menunjukkan bahwa tidak terdapat hubungan antara berat badan lahir bayi dengan asupan gizi mikro ibu ataupun dengan konsentrasi beberapa gizi mikro dalam darah (Vitamin A, B1, B2, B3, B6, B12 dan D). Jenis mineral lainnya yang dapat mempengaruhi berat badan lahir adalah zinc dan zat besi. Anemia defisiensi besi dapat menyebabkan bayi BBLR berdasarkan dari experiment terhadap hewan dan penelitian yang didapatkan dari manusia (Boer dkk., 2009).

Hasil penelitian ini menunjukkan bahwa tidak terdapat hubungan antarakonsumsi buah pada ibu hamil dengan berat badan lahir bayi di daerah pesisir. Penelitian Loy dkk. (2013) mendapatkan bahwa diet ibu hamil kebanyakan berdampak kecil pada berat lahir bayipada ibu yang bergizi baik. Namun, hasil ini menunjukkan bahwa asupan makanan pada jangka yang panjang selama kehamilan memiliki potensi untuk mempengaruhi pertumbuhan janin dan menentukan berat 
bayi saat lahir. Konsumsi makanan kaya mikronutrien berdampak baik pada pertumbuhan bayi.

Berbeda dengan penelitian Hassan dkk. (2011) yang mendapatkan bahwa berat lahir sangat berhubungan dengan asupan makanan ibu yang kaya mikronutrien pada semua tahap kehamilan. Peningkatan asupan susu dan sayuran berdaun hijau pada semua tahap kehamilan serta buah-buahan dari trimester kedua sampai akhir kehamilan dapat meningkatkan pertumbuhan janin (Hassan dkk., 2011).

\section{SIMPULAN}

Terdapat hubungan antara kebiasaan makan sumber karbohidrat, protein dan sayur pada ibu hamil dengan berat badan lahir bayi di daerah pesisir.Tidak ada hubungan antara kebiasaan makan buah pada ibu hamil dengan berat badan lahir bayi di daerah pesisir.

\section{SARAN}

Penyuluhan tentang sumber pangan lokal dan gizi ibu hamil penting dilakukan untuk meningkatkan pengetahuan ibu mengenai kebutuhan gizi selama hamil untuk perkembangan bayi sehingga dapat mencegah terjadinya BBLR.

\section{DAFTAR PUSTAKA}

Arkkola, T. 2009. Diet during pregnancy:dietary pattern and weight gain rate among finnish pregnant women. Universitasis Ouluensis: D medika 1037.

Boer, J.M.A., Van Bakel, A.M., Hoogervorst, E.M., Luijten, M., de
Vries, A. 2009. Effects of Maternal Diet during Pregnancy on Birth Weight of the Infant. National Institute for Public Health and the Environment.

Dinas Kesehatan Provinsi Sulawesi Tenggara. 2016. Profil Kesehatan Provinsi Sulawesi Tenggara tahun 2015.

Hassan, N.E., Shalaan, A.H., El-Mosry, S.A. 2011. Relationship between Maternal Characteristics and Neonatal Birth Size in Egypt. EMHJ-Eastern Mediterranean Health Journal 17(4): 281-289.

Kemenkes RI. 2014. Riset Kesehatan Dasar Tahun 2013: Badan Penelitian dan Pengembangan Kesehatan Republik Indonesia, Jakarta.

Kumar, R.K., Singhal, A., Vaidya, U., Banerjee, S., Anwar, F., Rao, S. 2017. Optimizing nutrition in preterm low birth weight infants-consensus summary. Front Nutr. 4:20.

Loy, S.L., Martazlina, M., Hamid Jan, J.M. 2013. Association between Maternal Food Groups Intake and Birth Size. Sains Malaysiana.

Ojofeitimi, E.O., Ogunjuyigbe, P.O., Sanusi, R.A., Orji, E.O., Akinio, A., Liasu, S.A., Owolabi, O.O. 2008. Poor Dietary Intake of Energy and Retinol among Pregnant Women: Implications for Pregnancy Outcome in Southwest Nigeria. Pakistan Journal of Nutrition 7 (3): 480-484.

Proverawati, A., Asfuah, S. 2009. Buku Ajar Gizi untuk Kebidanan.Yogyakarta: Nuha Medika. 
Saimin, J., dan Manoe, I.M.M.S. 2006. Hubungan antara berat badan lahir dengan status gizi ibu berdasarkan ukuran lingkar lengan atas. $J$ Med Nus 25 (3): 20-25.

Saimin, J., Faisal, M., Asmarani, Wicaksono, S. 2017. Peningkatan berat badan ibu hamil mempengaruhi berat badan lahir bayi di daerah pesisir. Preventif J. 2 (2): 70-4.

Sediaoetama, A.D. 2008. Ilmu Gizi Untuk Mahasiswa Dan Profesi. Jilid2. Jakarta: Dian Rakyat.

Shaikh, F., Zeeshan, F., Hakeem, R., Basit, A., Fawwad, A., Hussain, A., 2014. Maternal Dietary Intake and Anthropometric Measurements of Newborn at Birth. The Open Diabetes Journal.

Ullah, M.A., Haque, M.J., Hafez, M.A., Khanam, M. 2003. Biological Risk Factor of Low Birth Weight in Rural Rajshahi. TAJ 16 (2): 50-53

World Bank. 2006. Repositioning Nutrition as Central to Development: a strategy for large-scale action. Washington DC: World Bank. 